\title{
Pengolahan Produk Inovasi Bernilai Tambah dari Kearifan Lokal berupa Wadi Ikan Patin (Pangasius sp.) dengan Penambahan Wijen pada Poklahsar Tampung Parei Kota Palangka Raya
}

\author{
Value Added Innovation Product Processing from Local Wisdom in the form of Wadi Patin \\ (Pangasius sp.) with the addition of Sesame in Poklahsar Tampung Parei Palangka Raya City
}

Petrus Senas
Evnaweri
Tyas Wara Sulistyaningrum*
Department of Fisheries, Universitas
Palangka Raya, Palangka Raya,
Central Kalimantan, Indonesia
"email:
lilis_tyasningrum@fish.upr.ac.id
Kata Kunci
Inovasi Produk
Kearifan Lokal
Nilai Tambah
Keywords:
Product Innovation
Local culture
Value-added
Received: September 2019
Accepted: November 2019
Published: December 2019

\begin{abstract}
Abstrak
Kegiatan ini dilaksanakan pada Poklahsar Tampung Parei Jalan Tingang VIIB/Bukit Pengharapan No.2 Kelurahan palangka Kecamatan Jekan Raya Kota Palangka Raya pada Hari Selasa Tanggal 10 Septemnber 2019. Tujuan dari kegiatan ini adalah untuk melakukan pengalihan ilmu dan teknologi pengolahan produk olahan ikan bernilai tambah bagi Poklahsar Tampung Pare memanfaatkan kearifan lokal daerah sehingga dapat menghasilkan produk varian baru dengan. Membuka mind set peserta mahasiswa Prodi Teknologi Hasil Perikanan Universitas Palangka Raya untuk belajar berwirausaha dengan keterampilan yang di miliki untuk mensejahterakan kehidupannya kedepan. Kegiatan dilakukan dengan cara pemberian materi oleh Tim Pengabdian Kepada Masyarakat diskusi dengan pengusaha produk olahan ikan dan demonstrasi pembuatan produk baru dengan menambahkan bubuk wijen dalam produk olahan wadi patin. Produk olahan ikan bernilai tambah dari kearifan lokal daerah memiliki keunggulan dibandingkan produk lain, selain merupakan produk dengan variasi cita rasa baru juga dapat meningkatkan minat konsumen untuk membeli hingga meningkatkan pendapatan dan mensejahterakan masyarakat khususnya pengolahan hasil perikanan.
\end{abstract}

\begin{abstract}
This activity was carried out at Poklahsar Tampung Parei Jalan Tingang VIIB/Bukit Pengharapan No.2 Palangka Village, Jekan Raya Sub-District, Palangka Raya City on Tuesday, September 10, 2019. The purpose of this activity was to transfer knowledge and technology for processing valueadded fish products for added value. Poklahsar Tampung Pare utilizes local wisdom so that it can produce new variant products. The open mindset of participants of the Fisheries Product Technology Study Program at Palangkaraya University to learn entrepreneurship with the skills they have to prosper their lives going forward. The activity was carried out by giving material to the Community Service Team in discussions with fish processing products entrepreneurs and demonstration of the manufacture of new products by adding sesame powder to processed products of wadi patin. Value-added processed fish products from local wisdom have advantages over other products. Besides being a product with a variety of new flavors, it can also increase consumer interest in buying to increase income and improve the welfare of the community, especially fisheries processing.
\end{abstract} Services Universitas Muhammadiyah Palangkaraya. This is Open Access article under the CC-BY-SA License (http://creativecommons.org/licenses/by-sa/4.0/). DOI: https://doi.org/10.33084/pengabdianmu.v5i1.989.

\section{PENDAHULUAN}

Indonesia memiliki aneka ragam sumberdaya hasil perikanan yang sangat potensial untuk dikembangkan, tetapi pemanfaatan hasil perikanan di beberapa daerah di Indonesia belum dilakukan secara optimal. Oleh karena itu pengembangan dan penerapan diversifikasi produk olahan hasil perikanan perlu dilakukan, untuk 
menarik minat konsumen agar dapat meningkatkan nilai tambah produk, pendapatan nelayan, serta menambah asupan gizi bagi masyarakat (Mirza et al., 2017; Marsigit, 2010).

Pengembangan produk bernilai tambah masih sangat rendah, hal ini ditandai dengan pemanfaatan hasil produksi ikan yang masih didominasi olahan tradisional, dimana mutu hasil olahan masih kurang baik. Rendahnya tingkat pemanfaatan produksi yang masih didominasi dalam bentuk produk primer. Salah satu bentuk usaha pengembangan produk bernilai tambah adalah dengan merubah produk primer menjadi produk sekunder atau produk akhir siap saji seperti produk-produk kering atau snack, yang memiliki rasa yang gurih dan tekstur yang renyah (Togas et al., 2016). Pengembangan teknologi dilakukan untuk memenuhi tuntutan dan selera konsumen akan produk olahan hasil perikanan yang praktis, siap saji, bergizi tinggi dan bernilai tambah (Setiyorini et al., 2018). Selain itu juga agar dapat dikembangkan menjadi salah satu bentuk usaha dalam masyarakat, baik skala kecil maupun menengah. Produk bernilai tambah adalah suatu complimentary dari suatu teknik, diversifikasi dan peralatan yang diberikan pada produk sehingga produk mempunyai peningkatan ekonomi dan jaminan mutu yang meliputi ketahanan pangan (food security), keamanan pangan (food safety), dan pemanfaatan pangan (food utilization/consumption) (Saptana et al., 2014). Pengembangan produk bernilai tambah ini bertujuan meningkatkan nilai jual ikan sehingga akan meningkatkan pendapatan nelayan dan pengolah; mengoptimalkan pemanfaatan sumber daya ikan sehingga meningkatkan konsumsi protein masyarakat serta meningkatkan devisa negara.

Wadi ikan (hasil fermentasi ikan) adalah suatu produk ikan awetan yang di olah secara tradisional dengan metode penggaraman dan dilanjutkan dengan proses fermentasi. Selain garam dalam proses fermentasi juga digunakan padi, nasi atau keraknya sebagai sumber energi bagi mikroorganisme. Ikan yang akan di olah untuk bahan baku wadi haruslah berupa ikan segar dan hampir semua ikan air tawar dapat diolah menjadi wadi (Afrianto \& Liviawaty, 2009).

Wadi ikan adalah salah satu produk hasil fermentasi ikan, dengan tujuan mengawetkan daging ikan dengan cara menciptakan suasana asam dalam wadah tertutup. Agar proses pengasaman dapat berlangsung cepat maka dapat diberikan media penumbuh mikroba seperti beras atau padi sangrai yang di tumbuk halus. Jenis mikroba yang dapat tumbuh pada suasana asam, sefrta enzim yang mampu menghidrolisis lemak, selulosa dan protein (Choirunnisa et al., 2017; Khairina et al., 1999). Dalam prosesnya fermentasi ikan adalah sebagai berikut: tahap pertama terjadi pemecahan bahan organik kompleks menjadi lebih sederhana dengan bantuan mikroorganisme fakultatif tadi bersama dengan enzimyang menghasilkan substrat (asam asetat) bagi mikroorganisme untuk bahan cadangan pada tahap kedua (Mujdalipah et al., 2014). Untuk lebih jelasnya dapat diterangkan sebagai berikut: pada tahap pertama terjadi perombakan karbohidrat menjadi gula (maka terbentuk alkohol), pada tahap kedua terjadi perombakan alkohol menjadi asam asetat (suasana inilah yang terjadi pada proses pembuatan wadi ikan) (Undjung, 2014).

Produk olahan yang diproduksi oleh Poklahsar Tampung Parei merupakan produk kearifan lokal yang diolah dengan cara tradisional dan turun temurun, untuk itu dalam kegiatan ini akan di tambahkan bahan lain sebagai nilai tambah untuk produk dengan tujuan antara lain meningkatkan nilai jual ikan sehingga akan meningkatkan pendapatan pengolah, mengoptimalkan pemanfaatan sumber daya ikan sehingga meningkatkan konsumsi protein masyarakat, dan meningkatkan pendapatan pengolah (Dzulmawan et al., 2019). 
Target dalam kegiatan PKW ini adalah meningkatkan keterampilan para pelaku usaha pada poklahsarhasil perikanan dalam berinovasi menghasilkan produk olahan baru bernilai tambah dengan luaran yang diharapkan dari PKM ini adalah menghasilkan produk inovatif bernilai tambah dari kearifan lokal yang ada serta mentransfer iptek kepada mitra untuk peningkatan kesejehteraan.

\section{METODOLOGI}

Kegiatan pengabdian ini dilaksanakan pada hari Selasa Tanggal 10 September 2019 di mulai pukul 10.00-13.00 WIB. Kegiatan ini dilaksanakan dalam dua tahapan yaitu penyampaian materi mengenai pengolahan hasil perikanan bernilai tambah dan di lanjutkan dengan kegiatan demonstrasi pengolahan produk bernilai tambah. Lokasi kegiatan yaitu poklahsar TAMPUNG PAREI, Jl. Tingang VII B Bukit Pengharapan Kecamatan Jekan Raya Kota Palangka Raya. Dokumentasi kegiatan tim Pengabdian Bersama mitra disajikan pada Gambar 1.

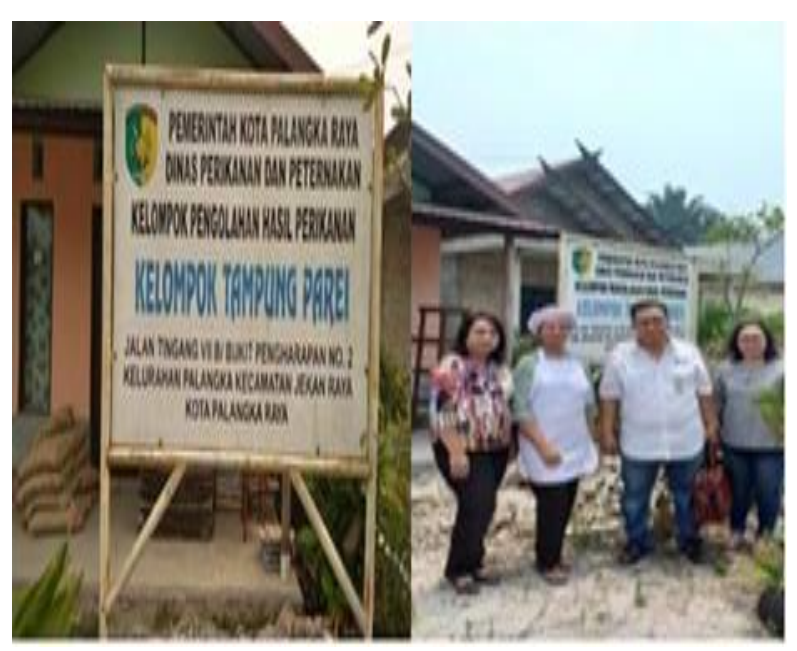

Gambar 1. Tim Pengabdian bersama Mitra

Bahan yang digunakan dalam kegiatan ini adalah seperangkat alat untuk sosialisasi (LCD untuk menyajikan materi, mikrophone dll), seperangkat alat untuk mengolah produk (bahan baku, bahan pembantu serta peralatan pengolahan). Bahan dan alat yang digunakan disajikan pada Gambar 2.

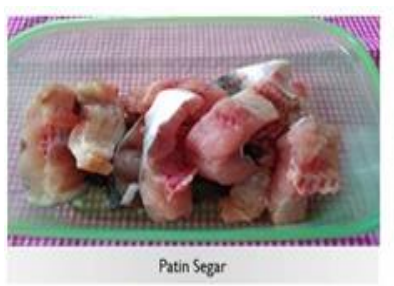

Gambar 2. Bahan dan Alat yang digunakan

\section{HASIL DAN PEMBAHASAN}

Kegiatan PKW dilaksanakan pada Hari Selasa Tanggal 10 September 2019, dimulai pukul 10.00-13.00 WIB. Kedatangan tim kegiatan pengabdian Program Kemitraan Wilayah PKW) beserta peserta dari Dinas Kelautan dan Perikanan Kota yang di wakili oleh dua orang penyuluh dan 16 orang mahasiswa dari sambut baik oleh Ketua Poklahsar Tampung Parei serta enam orang anggota kelompoknya. Kegiatan ini di bagi menjadi dua tahap, yaitu kegiatan penyampaian materi mengenai pengolahan produk perikanan bernilai tambah dari Tim PKW dilanjutkan dengan demonstrasi pembuatan produk pengolahan hasil perikanan bernilai tambah berupa wadi ikan patin dengan variasi lumu yang di gunakan. Produk bernilai tambah yang di hasilkan dalam kegiatan ini memiliki aroma yang menarik dan lebih harum dari produk dengan formula awal. Diharapkan produk ini akan menjadi salah satu produk andalan yang di olah dan di pasarkan oleh mitra kegiatan PKW ini yaitu Poklahsar Tampung Parei Kota Palangka Raya.

Dalam kegiatan ini tim PKW melibatkan 16 orang mahasiswa Prodi Teknologi Hasil Perikanan Jurusan Perikanan Universitas Palangka Raya dengan membuka mindset agar mahasiswa dapat mengembangkan diri dalam berwirausaha untuk mensejahterkaan kehidupannya kelak. Selain itu mahasiswa memperoleh keterampilan lebih mengenai cara pengolahan ikan hasil perikanan bernilai tambah dengan memanfaatkan 
kearifan lokal di Kalimantan Tengah khususnya kota

Palangka Raya. Dokumentasi kegiatan disajikan pada

Gambar 3 .
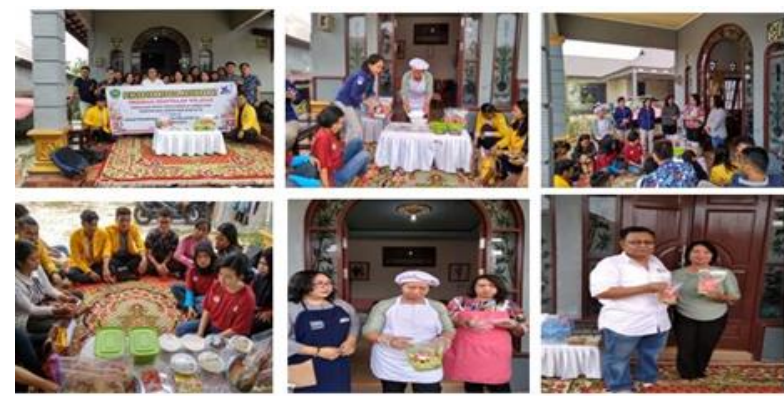

Gambar 3. Pelaksanaan Kegiatan, Pemberian Materi dan Demonstrasi

Luaran yang di capai dalam kegiatan PKW ini adalah sebagai berikut:

1. Terjadi pengalihan (transfer) ilmu dan teknologi pengolahan produk olahan ikan bernilai tambah bagi Poklahsar Tampung Parei dengan menghasilkan produk inovasi varian baru dengan memanfaatkan kearifan lokal daerah sebagaimana disajikan pada Gambar 4.

2. Membuka mindset peserta mahasiswa Prodi Teknologi Hasil Perikanan Universitas Palangka Raya untuk berani berwirausaha dengan keterampilan yang di miliki untuk mensejahterakan kehidupannya kedepan.

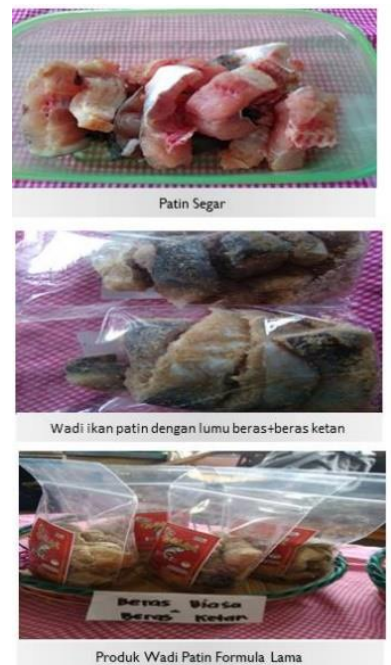

Produk Wadi Patin Formula Lama
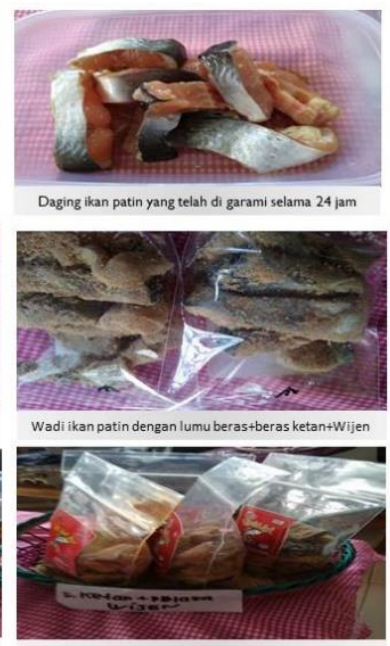

Produk Wadi Patin Formula Baru

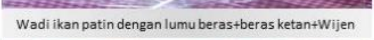

Gambar 4. Produk Wadi Ikan Patin dengan Penambahan Inovasi Terbaru

\section{KESIMPULAN}

Kesimpulan dari kegiatan ini adalah dapat menghasilkan produk wadi ikan dengan varian baru yang lebih menarik dari segi aroma dan rasa, mentransfer ilmu pengetahuan dan teknologi pada mitra Poklahsar Tampung Parei dalam mengolah produk perikanan bernilai tambah untuk aktif berinovasi untuk meningkatkan pendapatan, serta meningkatkan keterampilan berwirausaha bagi mahasiswa Prodi Teknologi Hasil Perikanan. Diharapkan kegiatan ini dapat terus berlanjut untuk memdukung dan mensejahterakan masyarakat dalam meningkatkan keterampilan dan pendapatannya.

\section{UCAPAN TERIMA KASIH}

Terima kasih kepada DP2M DIKTI dan LPPM UPR atas bantuan dana pengabdian yang bersumber dari DIPA PNBP Universitas Palangka Raya Tahun 2018 No. 042.01.2.400956/2019 Tanggal 20 Juni 2019 dengan No. Kontrak Program Pengabdian Kepada Masyarakat No. 514/UN24.13/PM/2019 dan fasilitas yang disediakan oleh pihak Mitra.

\section{REFERENSI}

Afrianto, E., Liviawaty, E. 2009. Pakan Ikan. Edisi Kelima. Yogyakarta: Kanisius.

Choirunnisa, H.N., Sari, R.Y., Hastuti, U.S., Witjoro, A. 2017. Identifikasi Dan Uji Kemampuan Hidrolisis Pada Bakteri Amilolitik Dan Proteolitik Yang Diisolasi Dari Wadi, Makanan Khas Kalimantan Tengah. Bionature. 18(2):99-109.

https://doi.org/10.35580/bionature.v18i2.61 38

Dzulmawan, M., Geo, L., Gafaruddin, A. 2019. Analisis Nilai Tambah Pengolahan Abon Ikan Tuna di Kelurahan Mata Kecamatan Kendari Kota Kendari (Studi Kasus Industri Rumah Tangga Dzakiyah Permata). JIA (Jurnal Ilmiah Agribisnis): Jurnal Agribisnis dan Ilmu Sosial 
Ekonomi Pertanian. 4(2):29-34. http://dx.doi.org/10.33772/jia.v4i2.6511

Khairina, R., Utami, T., Harmayani, E. 1999. Perubahan Sifat-Sifat Biokimiawi, Fisikawi, Mikrobiawi, dan Sensoris Produk "Wadi" Ikan Betok (Anabas testudineus Bloch). Agritech. 19(4):181-188.

https://doi.org/10.22146/agritech.13719

Marsigit, W. 2010. Pengembangan Diversifikasi Produk Pangan Olahan Lokal Bengkulu untuk Menunjang Ketahanan Pangan Berkelanjutan. Agritech. 30(4):256-264. https://doi.org/10.22146/agritech.9717

Mirza, A.C., Anggraini, R.A.R., Soetijono, I.R. 2017. Implementasi Pengelolaan Sumber Daya Laut Nasional Terhadap Kebijakan Pemerintah Provinsi Kepulauan Riau. Lentera Hukum. 4(2):79-94.

https://doi.org/10.19184/ejlh.v4i2.4758

Mujdalipah, S., Dohong, S., Suryani, A., Fitria, A. 2014. Pengaruh Waktu Fermentasi terhadap Produksi Biogas Menggunakan Digester Dua Tahap pada Berbagai Konsentrasi Palm OilMill Effluent dan Lumpur Aktif. Agritech. 34(1):56-64.

https://doi.org/10.22146/agritech.9523

Saptana, Sejati, W.K., Rusastra, I.W. 2014. Kemandirian Pangan Berbasis Pengembangan Masyarakat: Pelajaran Dari Program Pidra, SPFS, Dan Desa Mapan Di Nusa Tenggara Timur dan Jawa Barat. Analisis Kebijakan Pertanian. 12(2):119141.

http://dx.doi.org/10.21082/akp.v12n2.2014.1 19-141

Setiyorini, E.S., Noorachmat, B.P., Syamsun, M. 2018. Strategi Pemasaran Produk Olahan Hasil Perikanan pada UMKM Cindy Group. Manajemen IKM: Jurnal Manajemen Pengembangan Industri Kecil Menengah. 13(1):19-28.

https://doi.org/10.29244/mikm.13.1.19-28

Togas, C.D., Tambani, G.O., Jusuf, N. 2016. Analisis Kelayakan Usaha Budidaya Ikan Sistem Karamba Jaring Tancap Di Desa Talikuran Kecamatan Remboken Kabupaten Minahasa Provinsi Sulawesi Utara. Akulturasi: Jurnal Ilmiah Agrobisnis Perikanan. 4(7):317-326. https://doi.org/10.35800/akulturasi.4.7.2016. 13008
Undjung, D.T. 2014. Teknologi Industri Hasil Perairan. IPB Press. 